\title{
Administrative Aspects of Alternative Consumer Dispute Resolution in the European Union (EU), Slovenia and Croatia ${ }^{1}$
}

Urša Jeretina ${ }^{2}$

\begin{abstract}
The consumer field is widespread and often encompasses different legal fields on a single market, especially when it comes to the field of consumer protection. In fact, the consumer mostly remains a weaker party in resolving consumer disputes, especially in administrative proceedings. Traditional court proceedings do not always offer the most cost-appropriate way of resolving consumer disputes, because the damage with legal costs is disproportionate, especially in Small Claims (20 EUR). In theory, Alternative Dispute Resolution (hereinafter: ADR) is considered more flexible, faster and cheaper for disputes between consumers and businesses. Insofar, Consumer ADR (hereinafter: CADR) is seen as a useful tool that helps consumers realize their right of access to justice. It is argued that CADR systems provide valuable information on the needs of disputants, while preserving confidentiality, increasing consumer satisfaction, equality and grater trust. While CADR is praised in theory as an added value, in practice it still remains unrecognizable and therefore is seen as an ineffective formalism in some EU countries. It seems that consumers and businesses lack awareness of the CADR schemes and their benefits, which have effects on the efficient use of CADR in different public and private institutions. The

1 The paper was awarded as the "NISPAcee Best Graduate Student Paper" at the $24^{\text {th }}$ NISPAcee Annual Conference held in Zagreb, Croatia, May 19-21, 2016.

2 Urša Jeretina finished her Bachelor degree at the Faculty of Criminal Justice and Security, University of Maribor, and has just obtained her Master degree in Public administrative science at the Faculty of Administration, University of Ljubljana, Slovenia. After a successfully finished student internship within the Erasmus exchange program at the Croatian Mediation Association - CMA in Zagreb (Croatia) -, she had also efficiently finished a professional traineeship there. She is a mediator, mediation and administrative consultant and Head of Research and Development at Zavod UP - Institution for administrative operations in Ljubljana, Slovenia. She is now a $\mathrm{PhD}$ student in the $\mathrm{PhD}$ doctoral communication science study program at the Faculty of social sciences, University of Vienna, Austria.
\end{abstract}


focus of this paper is on the field of Public Administrative Law, which, through different approaches of scientific analysis, combines the main administrative aspects of CADR systems in the EU. Special attention is given to different administrative barriers in the development of various CADR schemes, which cause the formation of administrative dilemmas in some Member states. The new EU legal regulation on Consumer ADR, Online Dispute Resolution (ODR) and EU Administrative law have set flexible rules and principles that would assure the quality of dispute resolution between EU entities with private or public interests. Similarities in proposed principles would lead us closer towards a common European Administrative Space. However, so far such EU initiatives have left many questions unanswered regarding the supervision and financing of CADR schemes, as well as the administrative issues about the purely internal harmonization of "administrative" CADR practices in Member States. An example of the substantial administrative dilemmas in CADR practices, mostly in the field of universal services, can be recognized in existing CADR systems in selected EU countries, e.g. Slovenia and Croatia.

POINTS FOR PRACTICIONERS: Special attention is paid to the interplay between the CADR and public administration in the EU, which introduces us to various definitions of the concept of CADR in administrative proceedings. The theoretical view shows that the parties in consumer dispute resolution produce various legal relationships (C2B/G or G/B2C, B2B or G2B) of different legal natures (public or private interests), whether under administrative or civil law. Through comparative analysis of the concept of CADR in administrative proceedings among selected EU countries, divergences are shown in the legal framework of CADR procedures, existing CADR schemes and measuring efficiency tools for CADR procedures, which causes key administrative dilemmas in the main sectors of universal services. Despite divergences, some similarities appear between new principles of proposed new EU regulation, which could lead us closer to a common European Administration law. Unfortunately, the statistical analysis of existing CADR cases in selected Member states indicates an inefficient use of these pledged mechanisms. The given guidelines and improvements with one coherent CADR model contribute to the achievement and pursuit of the set goals towards an efficient European Administrative space.

\section{Key Words:}

Consumer Alternative Dispute Resolution, Consumer protection, Public Administration, CADR schemes, European Administrative Space.

\section{Introduction}

The wide scope of public administration often extends to different legal fields on a single market, which consequently combines several roles of the parties into only 
one (e.g. the citizen as a user, insurer, consumer etc.), especially in administrative proceedings. Every citizen sometimes appears in the role of a party in administrative proceedings, but more often they play the key role as a consumer on the single market. The consumer is anyone who works for their own needs on the single market. Europe consists of over 500 million consumers, and consumer expenditure amounts to $56 \%$ of the EU GDP (See European Commission 2011a, 2). In fact, the consumer field is spread out wide to different areas in relation to purchased goods and services, such as food, clothes, medicine, furniture, motor vehicles, various equipment, health, postal, gas and other services. Therefore, consumer protection is one of the key elements of the functioning of the EU single market, because it is beneficial for consumers and businesses; it supports economy growth, competitiveness and innovation. However, the EU could offer a more unified single market in the key universal sectors of everyday life, such as energy and telecommunications. The losses suffered by European consumers due to the problems with purchased goods or services are estimated at $03 \%$ of the EU GDP (e.g. Gallup Organization 2011). This particularly targets small claims in which consumers, harmed by the illegal practice of a trader, face difficulties in accessing effective and affordable means to obtain appropriate compensation (see DG SANCO 2011, 3-5). The consumers are unable to assess the risk of particular contracts, because they do not have comprehensive knowledge about all characteristics of demanding products and the quality standards pertaining to services, while they are heavily exposed to the psychological pressure of advertising.

Consumer disputes can be resolved judicially, as a judicial review, or, alternatively, as an (online) alternative proceeding, whether under civil or administrative law. But, judicial proceedings are not always the most cost-appropriate way for resolving consumer disputes, because they can be long and complex. Basically, for the amounts under 200 EUR, $48 \%$ of the EU consumers do not initiate court proceedings, while $8 \%$ of them never do so irrespective of the amount of their claim (e.g. TNS Opinion \& Social 2011). CADR can help enterprises to maintain good cooperation with consumers and gain a positive reputation in the EU internal market. With strong mutual cooperation between both parties, it also promotes competition. The main advantage of the efficient use of CADR and Online Dispute Resolution (hereinafter: ODR) is the increased satisfaction of the users who get another option to protect their rights - a process that is fair and appropriate and uses simpler, cheaper and faster dispute-resolution methods (see more in Jerenita and Uzelac 2014, 40). Additionally, it creates greater trust and equality between parties in the process, as well as the possibility of their further cooperation. However, while praised in theory as an added value, in practice CADR has not reached the desired levels; it still remains an unrecognizable tool or even an ineffective formalism in some EU countries.

In this paper, we analyze the concept of CADR through public administrative law, where various legal conceptions of consumer protection in administrative 
proceedings among EU Member states ${ }^{3}$ are shown. The definition of the legal relationship between the parties in CADR proceedings is complicated and complex. Namely, divergences occur in the definition of the parties in legal relationships with unlike legal nature, which produces distinct legal conceptions. Such legal conceptions are the result of various legal frameworks of CADR systems, the existence of distinct CADR schemes with divergences in their outcome (binding or non-binding) across EU Member states. In practice, there are more than 750 different ADR schemes in the EU (see DG - SANCO 2011, 6), which are all based on different procedures carried out by different public and private entities. That is the consequence of the EU proclamation that CADR can be carried out as a civil or as an administrative procedure and that the choice of the procedure is left to the Member States. The result of this free choice causes divergences in various areas of CADR systems with occurring administrative dilemmas that lead to an inefficient enforcement of consumer rights, mainly in the sectors of universal services.

Insofar, it is argued that the CADR and ODR systems provide an added value for both parties in a dispute. For instance, the process presupposes the involvement of an independent and neutral third party who seeks to secure the interaction between the parties and to facilitate finding consensual solutions to accomplish a winwin outcome. The parties are actively involved in the dispute settlement procedure and participate in the process of finding effective redress for their violated rights. Even so, despite all of the advantages of CADR and ODR proceedings, consumers and businesses do not use the full potential of these simple proceedings. The purpose of this paper is based on normative and comparative analysis to seek the main (positive and negative) administrative aspects of the CADR systems among selected EU Member states. The objectives are proposed through empirical analysis of the use of CADR schemes in public administration, which have shown to be key factors for the emergence of administrative dilemmas. The aforementioned guidelines and improvements, along with the development of one coherent CADR model applicable to all legal fields, efficiently create a more unified and participatory public administration in terms of good governance, which leads towards a common European administrative law.

\section{The interplay between consumer $A D R$ and public administration in the EU}

The interplay between CADR and public administration in the EU is reflected in a broad area of both legal fields. By examining both legal fields, it seems that they are closely intertwined and more often work hand in hand when it comes to consumer protection in administrative proceedings. In general, it is considered that the ad-

3 Through different scientific literature and legal frameworks, this issue proves to be non-harmonized definitions not only of consumers but also of traders, suppliers, providers and sellers. 
ministrative dispute resolution is not a form of ADR, although administrative ADR (especially negotiation rule-making) has been introduced in the United States (US) in APA (article 571-584) in the mid-1970s (see Perritt 1987, 863). Administrative ADR is apparently increasing in several EU member states, e.g. Sweden, the Netherland, Belgium, Finland, Norway, the UK etc. (Lindell 2012, 312), moving towards a more unified relationship between public administration and citizens as consumers. However, because of the specific character of public law, the problems occur in the process of legal conception (Goes 2014, 9). According to Perritt $(1987,863)$ "a major discrepancy between administrative procedure and the decision-making requirements of delegated legislative power was a failure to distinguish 'rights disputes' from 'interest disputes" in administrative law. The "interest disputes" are therefore characterized by the absence of pre-existing rules of decision, and adjudication is dealing just with "rights disputes" written by the rule of law. Although the administrative appeal may be included, in the broader sense, in the category of (C)ADR tools for the realization of the disputes by courts, it has been strongly recommended by the Council of Europe and has found its way into most of the jurisdictions, as well as into EU law ${ }^{4}$. Special rules in the field of administrative contract law are considered in the ReNEUAL Model Rules for administrative contracts ${ }^{5}$, because there is no consensus on the "public contract" definition. The ReNUAL has proposed that a public contract can be divided into three phases, which are usually common to all legal systems:

1. Administrative procedure leading to the conclusion of a public contract, governed by administrative procedure and public-procurement rules (e.g. the EU $\Leftrightarrow$ Member state (G2G), Member state $\Leftrightarrow$ Local Government, PSO or Regulatory agency (G2G or G2B/B2G);

2. Conclusion of the contract, governed by the rules establishing the prerequisites for the validity of a contract in the right to invoke invalidity (e.g. Public authority $\Leftrightarrow$ neutral or legal person (G2B/G2C or B2G/C2G), Regulatory agency $\Leftrightarrow$ $\mathrm{PSO}$ or consumer $(\mathrm{G} 2 \mathrm{~B} / \mathrm{B} 2 \mathrm{G}$ or $\mathrm{G} 2 \mathrm{C} / \mathrm{B} 2 \mathrm{C}$ or $\mathrm{C} 2 \mathrm{~B} / \mathrm{C} 2 \mathrm{G})$;

3. Execution and end (expiration) of the contract, above all governed by the law of obligations (e.g. EU $\Leftrightarrow$ Member state $\Leftrightarrow$ PSO (G2G or G2B/B2G), Member state $\Leftrightarrow$ PSO or PPP (G2G or G2B/B2G), PSO $\Leftrightarrow$ consumer (B/G2C or C2B/G). In the third phase it should be also considered whether the decision making process of the public authority, for the instance with regard to the exercise of contractual rights, the termination of the contract or the decision to enact a unilateral act in order to enforce contractual rights, has to be subject to administrative procedure rules.

4 See Dragos and Marrani in Dragos et al. 2014, 540.

5 ReNEUAL Model Rules on EU Administrative Procedure, Book IV - Contracts, Hofmann Herwig C. H., Schneider Jens-Peter, Ziller Jacques (eds), 2014, Version for on line publication. 
Therefore, the aim of administrative proceedings is an overall balance of public and private interests; more specifically of the appeal both interests are in terms of protecting the rights as a uniform, legitimate and effective dispute resolution between public authorities $(\mathrm{G})$ and private parties (C or B). Namely, the CADR mechanisms are the perfect option for efficient consumer protection in administrative proceedings. The CADR methods may be used in various legal relations between consumers and businesses $(\mathrm{C} 2 \mathrm{~B}$ or $\mathrm{B} 2 \mathrm{C})$ or in relations between businesses as private or private entities (B2B, B2G, G2B or G2G). But more often the consumer appears as a user of public service (e.g. telecommunication, energy, postal service, etc.) on the domestic market, which is a public body (C2G or G2C). The legal relationship between the consumers as users of public services and their operators is defined by the EU "acquis" as the use of "public services of general interest - PSO" or "universal service obligation - USO". ${ }^{\text {PSO }}$ or USO are considered to be carried out as an administrative matter that falls under the public administrative law. Additionally, in a consumer dispute resolution the legal relationships between the parties can be interpreted by various legal regulations, e.g. civil or administrative law. In the "administrative" (C)ADR proceedings, the public interest, in terms of market protection, is in line with the private interest, the protection of the weaker party - the consumer. If the public interest prevails over the private one, these administrative proceedings may be supervised by different administrative entities, e.g. regulatory agencies or the ombudsman. In some Member States, these agencies, because of their independence and autonomy, conduct ADR proceedings and may issue final administrative decisions if the parties do not reach a settlement. However, these decisions are binding for the trader, but the consumer has the right to an administrative appeal before the Administrative Court. Such dispute resolution may, therefore, take the form of multi-stage proceedings, initially conducted under the Administrative Procedure Act (APA) before administrative courts and at the same time before regular courts. However, to avoid multi-stage dispute-resolution proceedings, the importance must be given to more consensual legal conceptions regarding the "administrative CADR" with stronger mutual cooperation between all public and private parties in the dispute to achieve the goals and set principles of the European administrative space.

6 The services in general interest indicate "market" or "non-market" activities which are considered by the public authorities and are subjected to specific public service obligations (PSO) for this reason. The concept of "universal services" (under universal services obligations - USO) refers to a set of general requirements which should be satisfied by operators of such services to make sure that all citizens have access to certain essential services of high quality at prices they can afford. PSO and USO are more likely private bodies which provide goods and services in general interest and are mostly treated under public administrative law. See more in Europedia 2011 at http://www.europedia.moussis.eu/books/Book_2/3/6/06/4/?all=1. 


\subsection{Definition and legal status of Consumer ADR}

In general, CADR is considered an (online) ADR or out-of-court resolution of consumer disputes which helps consumers resolve their disputes with traders when they have problems with purchased goods or services on an internal market (EU). It is a faster, cheaper and more efficient tool with the presence of a third neutral party (a mediator, arbitrator, conciliator, ombudsman or similar person) who facilitates reaching a common settlement in resolving disputes between consumers $(\mathrm{C})$ and businesses as private or public entities (B or G). However, theoretically and normatively according to different authors and the EU legal regulation across Member states, there is no consensus on the definition of the parties - the consumer as well as the trader -, which is causing divergences in various legal relationships (e.g. $\mathrm{C} 2 \mathrm{~B}$ or $\mathrm{C} 2 \mathrm{G}, \mathrm{B} 2 \mathrm{C}$ or $\mathrm{G} 2 \mathrm{C}, \mathrm{B} 2 \mathrm{~B}$ or $\mathrm{G} 2 \mathrm{G}, \mathrm{B} 2 \mathrm{G}$ or $\mathrm{G} 2 \mathrm{~B})^{7}$ with a distinctive legal nature (e.g. interweaving of public or private interests). Both parties can be defined by various legal regulation (general and sectoral) with different legal conceptions under civil or administrative legal frameworks. The consumer ${ }^{8}$ can be interpreted as a citizen in relation to public authorities; a user of private or public services (e.g. bank, telecommunication, energy etc.); an insurer (or the policyholder) in insurance cases; a patient of health-care services; an independent entrepreneur as a user of public or private services and other. In addition, the trader ${ }^{9}$ can be interpreted in different roles on the single market: as a seller or supplier, provider, producer or manufacturer, distributor, importer of goods or services in public or private interests. Besides the non-common definition of the parties in dispute, the study of the Directorate General for Health and Consumers (hereinafter: DG-SANCO 2009, 9-10) has also revealed differences in the number of CADR bodies, the ADR schemes and procedures (arbitration, conciliation, mediation, in-house ADR etc.) and nature of the initiative (public or private).

Additionally, CADR mainly refers to the resolution of individual consumer cases, but it can also be a consideration of many similar cases joined together as the Collective

7 More about the e-commerce matrix in Agrar (2012), 12, available at http://repositorio.ual.es/ jspui/bitstream/10835/2208/1/Trabajo_7053_39.pdf.

8 "Consumer" means any natural person who is acting for purposes which are outside his trade, business, craft or profession. Directive on CADR 11/2013/EU, article 4.

9 "Trader" means any natural person, or any legal person irrespective of whether privately or publicly owned, who is acting, including through any person acting in his name or on his behalf, for purposes relating to his trade, business, craft or profession. Directive on CADR 11/2013/EU, article 4. 
redress ${ }^{10}$ (e.g. two models: opt-in and opt-out $)^{11}$, which, unfortunately, has still not become a daily practice in many countries (e.g. Latvia, Lithuania, Croatia, Slovenia, Bosnia and Herzegovina, Serbia etc. $)^{12}$. Collective redress strengthens the negotiating power of potential claimants and contributes to the efficient administration of justice by avoiding numerous proceedings concerning claims resulting from the same infringement of law. The European Commission (hereinafter: EC) identified two forms of collective redress: 1. injunctive relief, whereby claimants seek to prevent the occurrence of illegal behavior or its continuation; and 2. compensatory relief whereby damages are sought for the harm caused. These forms of the collective redress can be obtained not only before the court, but they may also be provided by using ADR mechanisms in the proceedings conducted by public or private representative entities (European Commission 2013, p.3-4). As another form of CADR mechanisms, the EU has provided a new option for all EU Member states, and that is the Online Dispute Resolution (ODR) for resolving cross-border disputes between traders and consumers via digital platforms. The ODR platform is easy to use with instructions in all European languages (online "Portal Your Europe"), which is pay-free and available to all consumers and businesses in the EU. The main advantages of the virtual settlement for consumer disputes are the voluntariness, informality and privacy of the procedure and also the faster final decision of cross-border dispute within thirty days. "Virtual mediators" play an important role and carry an increased responsibility to virtually facilitate the consensual decision on digital platform for parties from different Member States. The ODR procedure is extremely confidential, where information exchange enjoys strict protection of the data, although their use is transparent. Member States which have not yet adopted ODR implementation ${ }^{13}$ will be set up in four phases: 1. Establishment of the European ODR system; 2. Information on the EU-wide ODR system; 3. Data Protection Rules; 4. Monitoring.

10 Collective redress is a procedural mechanism that allows, for reasons of procedural economy and/or efficiency of enforcement, the bundling of many similar legal claims into a single court action. Collective redress facilitates access to justice, in particular in cases where the individual damage is so low that potential claimants would not think it worth pursuing an individual claim. See European Commission 2013.

11 "Opt-in" model means the group which includes only those individuals or legal persons who actively opt in to become part of the represented group. "Opt-out" model means the group which is composed of all individuals who belong to the defined group and claim to have been harmed by the same or similar infringement unless they actively opt out of the group.

12 Almost half the Member States did not introduce collective redress at all. In fact, only fourteen EU Member states (Austria, Bulgaria, Finland, France, Greece, Italy, Germany, Netherland, Poland, Portugal, Spain, Sweden and the United Kingdom (UK) provide mechanisms for mass claims processing regarding securities. Other Member States have redress mechanism introduced in their Consumer Protection Act, but have very little practical implementation in practice (for example Croatia). See more in Jeretina and Uzelac (2014), 49-51.

13 The final adoption of a comprehensive regulation to use ODR will take place at the beginning of 2016, which will also be followed by cyclical reports to the European Parliament on the introduction of the overall performance of the ODR platform. Member States will then gradually implement the ODR platform no later than by 2017, but first they had to implement various forms of ADR by the end of 2015. See more in Hodges (2012), 30-31, Hodges et al. (2012d), 22-23 and Rous (2014), 16-17. 
Insofar, $\mathrm{CADR}$ is a political priority for the $\mathrm{EU}$, which the $\mathrm{EU}$ institutions are promoting together with ODR systems. The EC developed an increased interest in the CADR, because it has the capacity to assure accessibility, equity, effectiveness, accountability and verification (see Hodges et al. 2012, 1-2). The beginnings of EU's special attention to the promotion and development of effective consumer protection date back to early 1975 . For instance, the CADR legal-basis regulation in the EU is provided by articles 114 and 169 of the Treaty on the Functioning of the European Union (hereinafter - the TFEU) ${ }^{14}$. The TFEU gives particular importance to consumer protection in terms of supporting the interests of consumers, providing high consumer protection and promotion of their rights by awareness-building, education and self-organization for the protection of their interests. The first steps in promoting CADR schemes were highlighted as "soft law" in two EC Recommendations. The first EC Recommendation was on the principles applicable to the bodies responsible for out-of-court settlement of consumer disputes ${ }^{15}$, which sets out the seven principles of independence, transparency, adversarial principle, effectiveness, legality, liberty and representation. These principles must be taken into account by the authorities in each Member State and their bodies that provide services for consumer disputes resolution. The second one was the EC Recommendation on the principles for out-of-court bodies involved in the consensual resolution of consumer disputes $^{16}$, which provides additional four principles of objectivity, transparency, efficiency and fairness to ensure greater choice and flexibility for consumers, particularly with respect to e-commerce and the development of communication technology. Furthermore, the EC drafted the Green Paper on Alternative Dispute Resolution in Civil and Commercial Law $w^{17}$ in 2002 with the aim to initiate a broad-based consultation of those interested in legal issues which arise in regard to ADR in civil and commercial law.

Parallel to the development of the EU, "soft law" also established formal legislation in terms of "hard law" and, therefore, different EU directives. A series of adopted directives in the field of consumer protection is called "Consumer acquis", which contain provisions on ADR schemes for consumer disputes, such as the Di-

14 TFEU, OJ L EU, No. 83/2010, 47-199. Article 114 regulates EU competences for the approximation of the laws concerning the establishment and functioning of the internal market, while article 169 lists the EU competences for the promotion of the interests of consumers and ensuring a high level of consumer protection. See also Juškys and Ulbaitė (2012), 26.

15 Commission Recommendation 98/257/EC of 20 March 1998, OJ L 115, 17. April 1998.

16 Commission Recommendation 2001/310/EC of 19 April 2001 on the principles for out-of-court bodies in the consensual resolution of consumer disputes (2001/310/EC), OJ L 109.

17 The Green paper on Alternative Dispute Resolution in Civil and Commercial Law (2002), COM (196 final). The Green paper has outlined three main reasons for growing interests in ADR: 1 . Increasing awareness of the ADR as a means of improving general access to justice in everyday life; 2. Considerable attention that ADR has received in a number of Member States; 3. Attribution of a political priority to ADR in the context of the information society and the promotion of ODR. 
rective on unfair consumer contracts ${ }^{18}$, Directive on electronic commerce ${ }^{19}$, Directive on credit agreements for consumers ${ }^{20}$, Directive concerning common rules for the internal market in electricity ${ }^{21}$ etc. There are also a number of EU directives as sectorspecific legal regulation ${ }^{22}$, which focus primarily on the critical area of universal services (telecommunication, tourism, energy, gas, postal and financial service etc.) and require the establishment of appropriate and effective CADR systems. The new EU legal framework for consumer disputes indicates the increasing support of CADR, but it is questionable whether the existing widespread European legislation can assure a consistent development of quality ADR providers in the Member States. Most CADR schemes do not distinguish between the purchase of goods or services by distance sales (e-commerce) and the methods of direct sales (personal sales). They tend to resolve all kinds of disputes in the area of their jurisdiction, regardless of whether it is electronic or conventional purchase (see DG SANCO 2011, 10). In order to increase consumer confidence in the single market, the EC adopted two new legislative frameworks: Directive on ADR for consumer disputes ${ }^{23}$ and the proposal for the Regulation on $O D R^{24}$. The Directive on CADR aims to encourage the formation of high-quality bodies for resolving contractual disputes related to the sale of goods and provision of services by traders. It also touches three main problems: 1. incomplete coverage of CADR at sectoral and geographical level, 2. consumers' and businesses' lack of awareness about existing ADR bodies, 3. variable quality of CADR. The regulation on ODR should enable businesses and consumers

18 Directive 93/13 EEC of 21 April 1993 on unfair in consumer contracts, OJ L 95.

19 Directive 2000/31/EC on certain legal aspects of information society services, in particular electronic commerce, in the Internal Market (Directive on electronic commerce), OJ L 178/1.

20 Directive 2008/48/EC on credit agreements for consumers and repealing Council Directive 87/102/EEC, OJ L 133/66, 66.

21 Directive 2009/72/EC on concerning common rules for the internal market in electricity and repealing Directive 2003/54/EC, OJ L 211/55, Directive 2009/73/EC concerning common rules for the internal market in natural gas and repealing Directive 2003/55/EC, OJ L 211/94, 55, 94.

22 Such as Directive 2009/136/EC amending Directive 2002/22/EC on universal service and users' rights relating to electronic communications network and services; Directive 2002/65/EC concerning the distance marketing of consumer financial services, z dne 9. October 2002, art 14; Directive 2008/122/EC of 14 January 2009 on the protection of consumers in respect of certain aspect of time share, long-term holiday product, resale and exchange contracts (art 14(2)), OJ L 33, Art 14.; Directive 2008/6/EC amending Directive 97/67/EC with regard to the full accomplishment of the internal market of Community postal service, OJ L 52, 3.; Directive 2002/92/EC of 15 Januar 2003 on insurance mediation (Art 11(1)), OJ L 9, Art 11.; Directive 2004/39/EC on markets in financial instruments amending Council Directives 85/611/EEC and 93/6/EEC and Directive 2000/12/EC and repealing Council Directive 93/22/EEC, OJ L 145/1, 33 and others.

23 Directive No 2013/11/EU of the European Parliament and of the Council of 21 May 2013 on Alternative Dispute Resolution for consumer disputes and amending Regulation (EC) No 2006/2004 and Directive 2009/22/EC (Directive on consumer ADR).

24 Regulation (EU) No 524/2013 of the European Parliament and of the Council of 21 May 2013 on Online Dispute Resolution for consumer disputes and amending Regulation (EC) No 2006/2004 and Directive 2009/22/EC (Regulation on consumer ODR). 
to directly access an online platform, established at an intermediary body in accordance with the Directive as assistance in resolving contractual disputes related to cross-border online transactions. The new CADR legal regulations are a part of the twelve key actions of the Single Market Act. ${ }^{25}$

The new EU policy aims that empowered consumers are the heart of the single market, which is supported by the new EU Consumer program (2014-2020) ${ }^{26}$ and Management Plan (2014). ${ }^{27}$ The new program will achieve this aim by contributing to the protection of health, safety and economic interests of consumers and promoting their right to information, education and to organize themselves to protect their interests, also on digital platforms. These objectives also support the set goals of the European 2020 Strategy $^{28}$, which includes specific questions about the digital agenda, sustainable growth, social integration and smart regulation. This new Strategy calls for "citizens to be empowered to play a full role in the single market", which "requires strengthening their ability and confidence to buy goods and services cross-border". Therefore, it is important to create an efficient CADR framework within which consumers can rely on the fundamental principle that ensures safety, detects inefficiency of set quality standards and addresses them effectively across Europe.

\subsection{The current stage of Consumer ADR}

The current stage of CADR systems in the EU is complicated and complex. In practice, more than 750 different ADR schemes have been identified across member states relevant to consumer-to-business disputes, of which less than 500 have been notified to the EC, but there were also 288 non-notified ADR schemes identified across the

25 See European Commission (2012a). Single Market Act II, Together for new growth, COM (573 final). It contributes to the formation of a "strong, deep and integrated" European market which "creates growth, generates jobs and offers opportunities".

26 European Commission (2014): Consumer programme 2014-2020, see more at http://ec.europa. $\mathrm{eu} /$ consumers/strategy-programme/financial-programme/index_en.htm.

27 DG-SANCO (2014): The main problems that need to be addressed are signed in the following categories with specific aims for consumer policy: Security (enhancing product safety through effective market surveillance throughout the EU), working for and with consumers (increasing visibility of EECs), making markets work for consumers (adopting proposed measures for greater transparency and comparability of bank fees, flexibility of transfers of payment accounts), going digital (implementing Digital Agenda 2014 - "EU consumer in the digital era"), strengthening rights and redress (enforcing consumer redress to consolidate consumer rights), enhancing knowledge ("know how" through the "Consumer Scoreboard") and ensuring better implementation and enforcement (unlocking the full potential of the Single Market with the enforcement of consumer rights by strengthening cooperation between national enforcement bodies through Consumer Protection Cooperation (CPC) network).

28 See European Commission (2010, 5): Europe 2020, a strategy for smart, sustainable and inclusive growth, which proposes seven important initiatives: 1 . an innovation union, 2 . youth on the move, 3. a digital agenda for Europe, 4. a resource-efficient Europe, 5. an industrial policy for the globalized era, 6. an agenda for new skills and jobs and 7. a European platform to tackle poverty. 
EU. ${ }^{29}$ Additionally, the EC has developed a database of more than 400 ADR schemes ( $40 \%$ of all ADR entities) which they deem to conform with the principles set up in the EC Recommendations. They are all based on different procedures carried out by different entities under different sectoral or general legislation (e.g. civil or administrative). However, most of ADR schemes are available to consumers free of charge or at a reasonable price (under 50 EUR) and are usually resolved within a short time (30-90 days on average). The CADR procedure may be entrusted to a collective body (e.g. a committee or commission for complaints) or to an individual person (a mediator, conciliator, arbitrator or ombudsman). The final outcome of the process may be a settlement, a non-binding recommendation or a binding decision. If binding, the decision may be binding only for the trader (unilaterally) or for both parties (bilaterally). This means that practically every scheme of CADR is unique.

CADR schemes are broadly available in the area of universal services, such as the financial-services sector (payment services, consumer credit), insurance, telecommunication, transport and postal services. However, in the energy, gas and tourism sectors they are still in the developing stage. In fact, some characteristics, such as the compulsory membership, the binding nature of the final decision and the exchange of information within regulatory authorities, are more common in these sectors than in the others. The EU initiatives ought to further promote the development of common ADR schemes in these particular sectors (European Commission 2012a, 6), mainly because of the importance of universal services. Furthermore, CADR and Collective redress are also working hand in hand in a number of areas and various services sectors, be it in court proceedings, in out-of-court mandatory procedures or in judicial or voluntary agreement. According to Hodges $(2012,11)$, “... the interests of economy (e.g. bank charges, unfair commercial practice, medicine etc.) suggest that similar issues should be dealt with together, so as to achieve coherent, consistent and economical results." Although collective redress mechanisms are not introduced in all member states (ibid., 4), they may prove to be helpful to potential groups of consumers (or public interest representative) in compensation for the damage caused by an unlawful conduct of the trader. These mechanisms were in the process of adoption till the end of 2015 (European Commission 2011a, 5), but they have still not been imposed as a daily practice in all member states. For this reason, in 2011, the EC carried out a horizontal public-consultation document: "Towards a coherent European approach to collective redress", the aim of which was to identify common legal principles on collective redress and to examine how such common principles could fit in the EU's legal system.

Essentially, diversities and divergences in CADR schemes and models across the EU have been discovered, mainly on the functioning of the CADR bodies, the financing component, sectoral differences and geographical coverage. However,

29 DG SANCO has commissioned a number of studies on consumer ADR that have identified major divergences of the national ADR entities in terms of their sector-specific and geographical coverage. See DG-SANCO (2009), 8-30. 
three types of structures for CADR systems can be broadly identified across different sectors and countries (see Hodges et al. 2012d, 400):

1. CADR agreements within public regulatory bodies (e.g. Germany, France, Lithuania and the UK);

2. Independent decision-making bodies (e.g. the Netherlands, Slovenia, Nordic, the UK and Germany);

3. Dispute Resolution arrangements sponsored by a trade association in order to resolve dispute arising under a code of business practice (e.g. the UK).

Additionally, CADR mechanisms stretch to both private and public decisionmaking bodies, which means that the public and private are constantly in interplay. Unfortunately, we cannot clearly separate both legal fields, because the public domain is sometimes concealed in the private legal area, which makes it discrete and hard to define. This leads us to a number of legal conceptions with different legal relationships in various existing CADR schemes provided by different CADR bodies with divergences in their outcome: binding or non-binding decisions.

In order to improve the functionality of the common EU market with the power to increase CADR practice and to harmonize national legal regulations in terms of effective cross-border CADR mechanisms, the EC has set up three networks: FIN-NET (Network of ADR entities for financial services) ${ }^{30}$, the ECC-NET (European Consumer Centers) ${ }^{31}$, and SOLVIT ("online problem solving network"). ${ }^{32}$ All three networks are a step forward to a common and harmonized CADR model with the coherent legal regulation across member states. However, set networks have not yet reached the desired levels, and consumers have not explored its full potential

30 Financial Services Complaints Network, established for the development of special ADR bodies on the basis of the document - Commission 98/257/EC on the principles applicable to the bodies responsible for out-of-court settlement of consumer disputes, OJ L 115/31. FIN-NET is a network of national ADR, which deals with cross-border disputes between consumers and financial service. FIN-NET has 50 members of which there are 19 EU Member states and Ireland, Liechtenstein and Norway. This means that Bulgaria, Cipher, Estonia, Hungary, Lithuania, Romania, Slovakia, Slovenia and Croatia are still not members of FIN-NET.

31 European Consumer Centers Network, established as Extra-Judicial Network (EEJ-NET) with the EC Resolution 2000/C on a Community-wide network of national bodies for extra-judicial settlement of consumer disputes, OJ C 155/1. ECC-NET is a European network particularly for consumer protection, which directs consumers to an adequate ADR body. From the Annual reports of EEC-NET (2005-2009) the number of ADR cases in the EU is shown, which has in the last two years increased from 410,000 in 2006 to 530,000 in 2008 (DG SANCO 2009, 13), but it has not yet achieved its whole potential. In 2009, EEC-NET received 6.6\% cross-border complaints that were carried by ADR, while in 2010 only $5 \%$ of EU consumers and $9 \%$ of EU traders used ADR (European Commission 2011b, 2).

32 SOLVIT is an online network the aim of which is out-of-court settlement in legislation misapplication by public authorities on the single market. In practice, such errors are rare, otherwise in 2011 most number of cases were issued in the field of social security, rights of residence, professional qualifications, drivers' rights etc. See SOLVIT Annual Report 2010-2012 at http:// ec.europa.eu/SOLVIT/. 
(e.g. small number of cases). According to Juškys and Ulbaite $(2012,27)$, “... the official exchange between the ADR entities is also very low and mainly limited to the European Commission-sponsored mediation activities of the ECC-NET and FINNET. Such a situation may be explained by the fact that the Commission Recommendations have a non-binding character, and the Member States are free to decide on the model of consumer ADR at the national level."

The EU needs to build an overall environment with "smart" policies, where consumers can rely on the basic premise of safety through education. This is the only way towards fully empowered consumers, which helps them effectively benefit from the best offers on goods and services. In such an environment, the consumers are able to make informed decisions, and they could also have the greater impact on strengthening the Single Market and stimulating growth by demanding value, quality and service (European Commission 2011a, 2). The important tools for effective protection of consumers' rights are ADR and ODR schemes, which can put empowered consumers at the heart of the Single Market.

\subsection{The main administrative aspects of Consumer ADR in Slovenia and Croatia}

Some administrative problems of CADR in the EU with public and private prospects are presented in the paragraph above. However, the main administrative aspects of CADR are seen particularly in Slovenia and Croatia, which have developed CADR systems in rather different manners despite their similar histories, traditions, legal cultures and social mentalities. Both member states started developing CADR practices from the early 2000s on under the influence of implementing the EU legislation. The ADR schemes in consumer matters were promoted in different sectors, both public and private. At first, ADR mechanisms were introduced mainly in the courts of law, later more specific ADR schemes were formed in specific sectors of different services, such as banks and insurance, telecommunication, payment, energy and other services. However, the use of these arrangements is still limited and complex. Therefore, the main administrative aspects regarding CADR procedures in Slovenia and Croatia are highlighted in the table below:

General CADR schemes are presented in the table above, which are almost the same in both countries, although they are carried out by different CADR entities with binding or non-binding final out-comes. In fact, some experiments in introducing ADR in the Slovenian court system date back to the late 1990s (see Galič in Hodges et al. 2012d, p. 197), while the development of introducing ADR in Croatian courts took place in the 2000s. ${ }^{33}$ However, not all Croatian courts include ADR in their judicial system so far. Later on, different ADR schemes were established in

33 See, e.g., Mediation Act 2003 and Croatian Phare project on the introduction of court-annexed mediation in Croatian courts (2005-2009), available at http://www.mirenje.hr/index.php/o-nama/openite-informacije.html and http://www.vtsrh.hr/index.php?page $=$ conciliation\&lang $=\mathrm{hr}$. 
special fields of the business sector, mainly in the area of universal services, such as telecommunication, energy, health, labor, traffic, postal, bank and insurance services. Such services have established different CADR schemes (e.g. mediation, conciliation, in-house complaint or conciliation procedures, arbitration, courts of honor etc.), and some of them are part of the public or private domain, e.g. regulatory agencies or public-private providers of universal services in both member states. Some differences are shown as well, for instance, the Slovenian chambers that imposed ADR mechanisms (mostly mediation and arbitration) are completely private (e.g. the Slovenian chamber of Commerce), while the Croatian chambers are still a part of the public administration law (e.g. the Croatian chamber of Commerce, the Croatian chamber of Trades and Crafts etc.). Furthermore, almost all main Croatian CADR bodies are completely private (e.g. Associations and Bureaus), except the courts and chambers, but they maintain strong mutual cooperation, which makes them more successful. The main public CADR bodies in Slovenia are normatively the courts, regulatory agencies and also universal services (e.g. telecommunication and energy), while the main private ADR bodies are mostly chambers and associations on the field of commerce, health, finance and advertising.

As a consequence of a constant interplay between the private and public CADR mechanisms, different types of legal relationships occur between the parties in a consumer dispute, which have, because of various legal statuses and natures, different legal consequences (binding or non-binding). The relations of the CADR proceedings in Slovenia can range from simple (e.g. $\mathrm{B} 2 \mathrm{~B}, \mathrm{C} 2 \mathrm{~B}$ or $\mathrm{B} 2 \mathrm{C}, \mathrm{C} 2 \mathrm{C}$ ) to extremely complex ones (e.g. G2G, G2C or C2G, B2G or G2B), where one party can be completely private (B) or half private and half public in a public-private partnership (B or G). Legal relationships in Croatian CADR proceedings are so far mainly in the private area; although with the transposition of the new EU legislation, these relations will also touch some public bodies (e.g. regulatory agencies). The main problem is in the final outcome of these complex CADR techniques. Generally, if no consensual settlement is reached by CADR in both countries, the parties have the right to appeal before regular courts. However, as a specialty in the Slovenian CADR system, if no settlement is reached by a public CADR body, a reasoned administrative decision could be issued as a non-binding recommendation for the consumer and a binding decision for the trader. In this case, the consumer has the right to appeal before the Administrative court, but the trader can file a lawsuit on the regular courts for the same case, which causes a multi-stage decisionmaking process. These administrative dilemmas have a negative impact on the practical importance of CADR schemes. In Croatia, issuing non-binding recommendations and decisions is generally not prohibited (if not expressly excluded by the parties' agreement). On the other hand, CADR decisions are generally binding in administrative or civil CADR proceedings. However, the ability to directly enforce the final decision in both countries depends on whether the CADR proceeding was conducted by the court or by a private CADR institution. If a settlement is reached in a court-annexed scheme, the settlement is generally regarded to have the force of a court-negotiated settlement, 


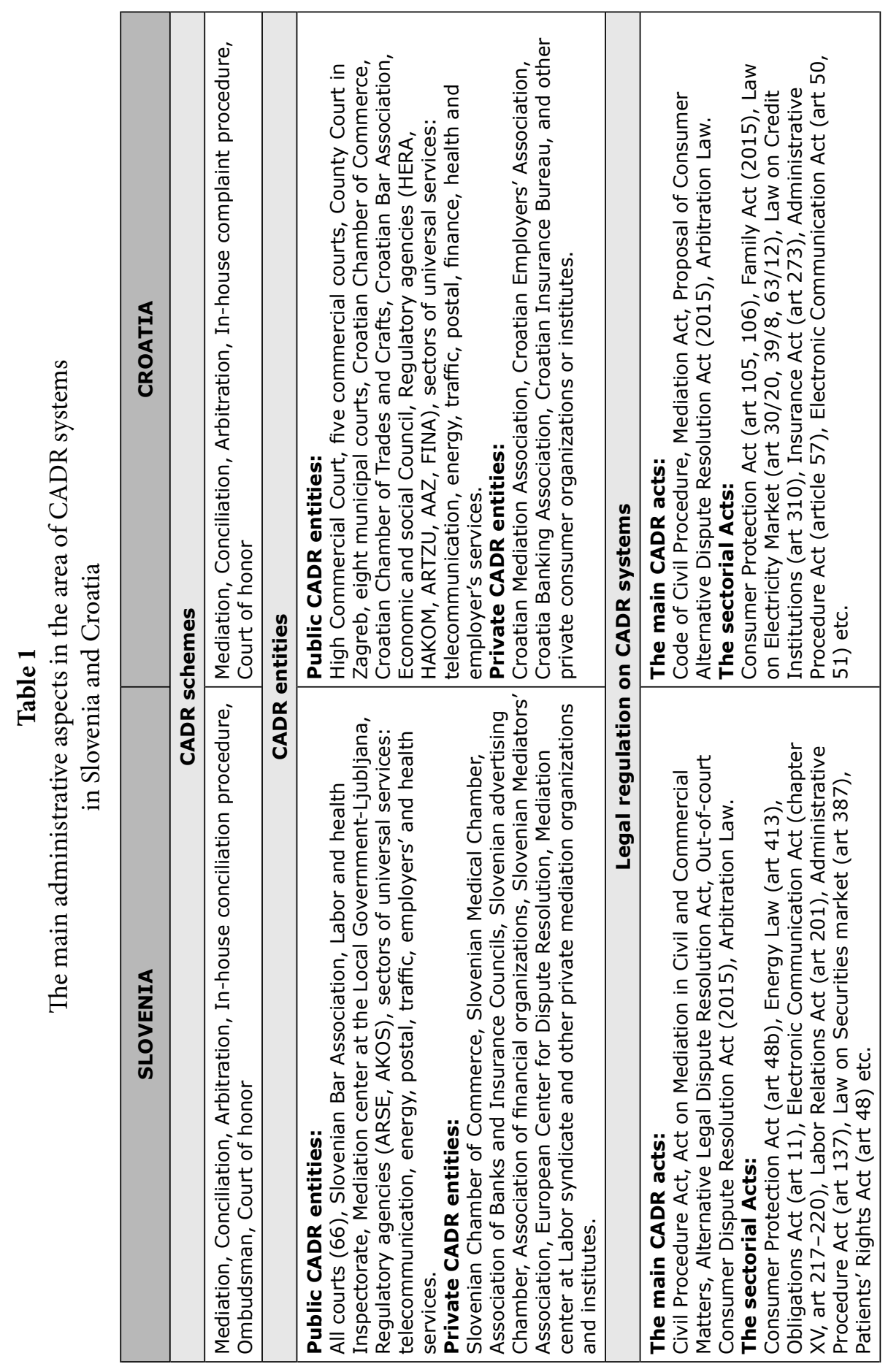




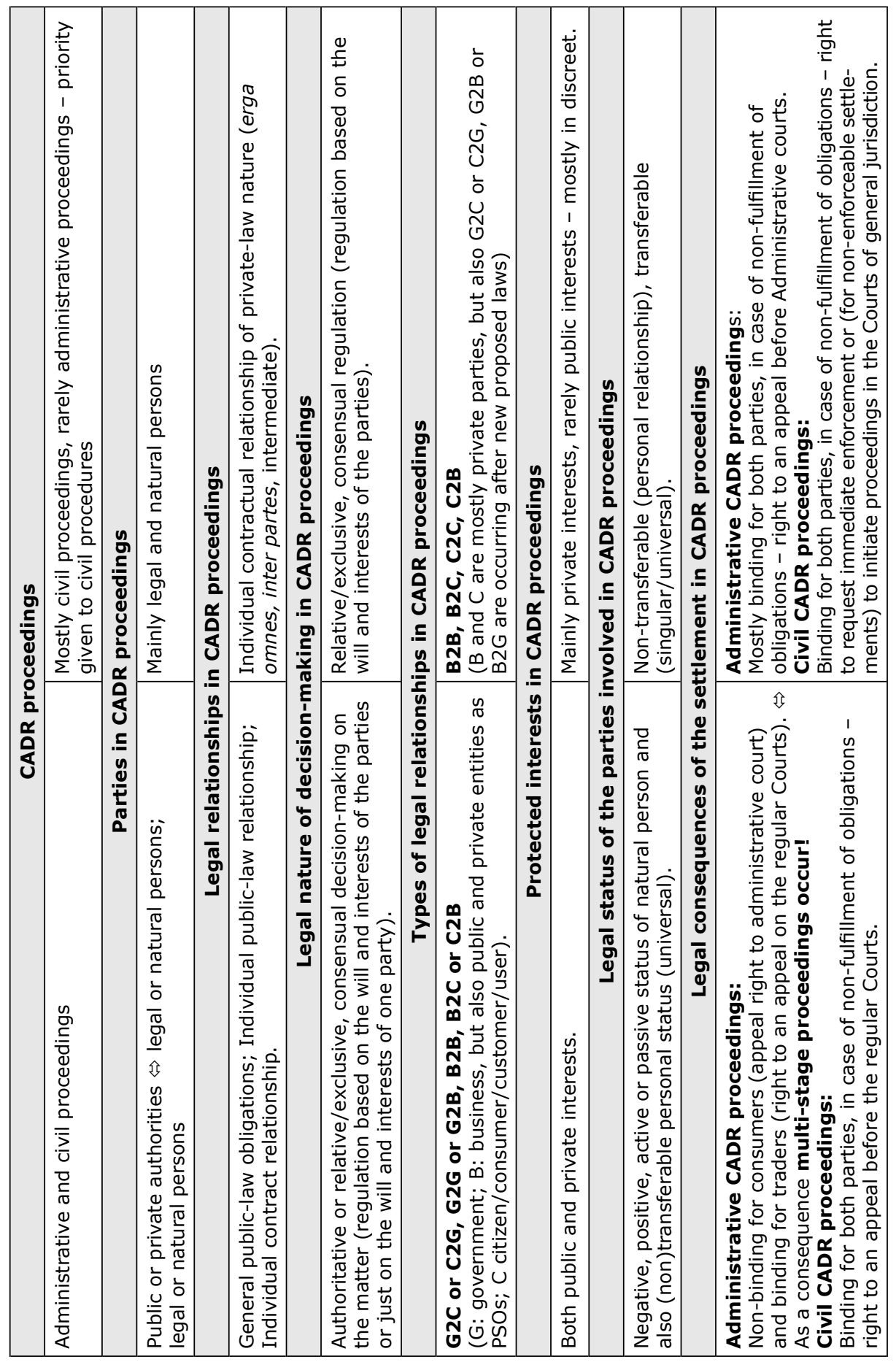


which is directly enforceable. In spite of legal provisions that wanted to give the same effect to the settlement reached before private CADR institutions, these settlements experience difficulties in their enforcement in practice. With the CADR legislative plans, both member states should address this problems, which should erase existing administrative dilemmas, especially in Slovenia.

\subsection{Research questions}

1. [RQ1]: The transposition of various European legal regulations on consumer protection into member states' legislation systems causes various legal conceptions of the parties in consumer dispute resolution, whether under administrative or civil law. The main administrative aspects of CADR systems cause inefficiency of CADR proceedings in public and private entities. What are the main administrative aspects for inefficient use of CADR systems in EU?

2. [RQ2]: The interplay between CADR systems and the public administration in the EU has an impact on the efficiency of set goals of the European administrative space. What can be done for a more common European administrative space in the area of consumer protection?

\subsection{Data and Methods}

In the proposed paper, we use different research methodologies, techniques and analyses. We first use theoretical research methods, classifying, identifying and differentiating the CADR systems with the EU legislation through the public administrative law. With the theoretical data analysis on the widespread fields of consumer dispute resolution and public administration, the constant interplay between the public and private domains is shown, which is a consequence of the non-harmonized definition of the parties in a consumer dispute, whether under administrative or civil law. Through a comparative survey of the consumer protection concept in administrative proceedings among selected EU countries, different CADR legal frameworks and various existing CADR schemes are displayed within different public or private CADR bodies. By using comparative and compilation methods, we define the main administrative aspects in existing Slovenian and Croatian CADR mechanisms, where key administrative dilemmas in some sectors of universal services occur. The results of the theoretical and comparative research show some interesting compilation and similarities between the principles of EAS and CADR legal structure. With the empirical analysis of the Slovenian and Croatian CADR practices, we reveal divergences in existing CADR schemes and their inefficient use. The results of the empirical analysis show the current stage of Slovenian and Croatian CADR administrative proceedings. By identifying the main administrative aspects of CADR in the EU, we have been able to propose important guidelines for an efficient European administrative space with the sense of good governance towards common European Administration Law. 


\section{European administrative space empowered by consumer ADR}

To avoid discretionary decisions, the EU has required new strategies and governance, such as online administration systems that represent new procedural mechanisms and rules, which are much more flexible and informal than those in traditional hierarchical models of government. New administrative procedures within governance must contribute to different principles, such as openness, citizen and inter-agency participation, accountability, effectiveness, and coherence (see more in Barnes 2009). These principles are a part of the so-called "acquis communautaire", which is the entire body of legislation of the European Community. In addition to the differences in public administrations across the EU Member States, there was a need for the development of these common European principles, rules and regulations, which are known as the European Administrative Space (hereinafter: $E A S$ ) (see OECD-PUMA 1999). EAS is derived from the rule of law and democracy, which must be adjusted to these new methods in administrative procedures on all levels of public administration. According to Cioclea (2012): "The main interest of $\mathrm{EU}$ is ensuring that each national administration offers comparable administrative capacity through quality of public services and professionalism from the civil servants. Along that, the European states are characterized by long and varied institutional histories, with different projections in their evolution."

The above principles are a concrete form of quality regulation standards enshrined in the regulatory policies of the EU and its Member States. As Cardona and Freibert (2007) noted: "As far as these principles are shared among EU Member States and implemented in their public administrations not only theoretically, one can speak of a common EAS." Essentially, these EAS principles can be fulfilled through principles of CADR systems across EU. OECD-PUMA (1999) has required the main administrative law principles that are common to Western European countries, which are distinguished in the following groups through set CADR principles of EU Directive 11/2013/EU:

1. Rule of law, legal certainty - reliability and predictability of administration actions and decisions, which refers to the principle of legality as opposed to arbitrariness in public decision-making and to the need for respect of legitimate expectations of individuals (neutrality and generality, legal competence, discretion, proportionality, fairness, timeliness, integrity).

The rule-of-law principle can be achieved with the principle of expertise, independence and impartiality (Article 6), which means that the natural person in charge of ADR proceeding possesses the necessary expertise - knowledge and skills in the field of alternative and judicial consumer dispute resolution, as well as a general understanding of the law. Meanwhile, this person also has to ensure the independence, neutrality and impartiality of their action in the ADR pro- 
ceedings. In the ADR process, importance is given to the principle of fairness (Article 9) under which the parties have the possibility to express their point of view, to be provided by the ADR entity with the arguments, evidence, documents and facts put forward by the other party, and statements made and opinions given by experts, and to comment on them. The parties are informed and notified about the outcome of the ADR procedure in writing or on a durable medium and are given a statement of the grounds on which the outcome is based. The parties also have the possibility to withdraw from the procedure at any time if they are dissatisfied with the performance or the operation of the procedure. Otherwise, the parties have a choice to agree or not to agree to, or follow, the proposed solution, which may be different from the outcome determined by a court applying legal rules. Furthermore, before agreeing to, or following, a proposed solution, the parties are informed of the legal effect of agreeing to, or following, such a proposed solution, and before expressing their consent to the solution or agreement, they are allowed a reasonable period of time to reflect. In CADR proceedings, parties receive so much freedom in the process of resolving their disputes normally within the limits of the rule of law, which makes them efficient and open to other possibilities of further cooperation.

2. Openness and transparency aimed at ensuring the sound scrutiny of administrative processes and outcomes and its consistency with pre-established rules (responsibility, statement of reasons).

Transparency and openness can be achieved through Article 7 of the Directive on CADR, assuring that ADR entities make publicly available clear and easily understandable information on their complete functioning (e.g. contact point; expertise, impartiality and independence of natural persons in charge of ADR; membership and networks of ADR entities facilitating cross-border disputes; the types of disputes they are competent to deal etc.) on their websites, on a durable medium upon request, or by any other means they consider appropriate. The directive has given special attention to ensuring consumer information by traders and cooperation with exchanges of experience between ADR entities and national authorities in Chapter III. By assuring the high level of cooperation between ADR entities and also between parties, we could achieve efficient openness and transparency, which are the main principles of efficient and good governance.

3. Accountability of public administration to other administrative, legislative or judicial authorities, aimed at ensuring compliance with the rule of law (supervision, to explain and justify its actions).

The accountability principle is displayed with the rule of law through the principle of liberty (Article 10) and the principle of legality (Article 11). Liberty can be achieved by ensuring an agreement between the parties to submit complaints to an ADR entity, which is not binding on the consumer if it was concluded 
before the dispute, has materialized and if it has the effect of depriving the consumer of his right to bring an action before the courts for the settlement of the dispute. Otherwise, the legality can be ensured with the aim of ADR procedures, which is resolving the dispute by imposing a solution that may be binding on the parties only if they were informed of its binding nature in advance and they specifically accepted it. Specific acceptance by the trader is not required if national rules provide that solutions are binding on traders. Furthermore, in the ADR, it is also possible to impose a solution on the consumer in a situation where there is no conflict of laws or in situations involving a conflict of laws, where the law is applicable to the sales or service contract or to contractual obligations. ${ }^{34}$ The directive has revealed the purpose of binding and non-binding settlements and when they can be used and proposed. This is a step towards a harmonized CADR model across Europe, which is leading us to coherent EAS.

4. Efficiency in the use of public resources and effectiveness in accomplishing the policy goals established in legislation and in enforcing legislation ("the three E's method").

Efficiency can be made by effective ADR procedures (Article 8), which are available and easily accessible online and offline for all parties regardless where they are. The parties have access to the ADR procedure without being obliged to retain a lawyer or a legal advisor. The ADR procedure is free of charge or available at a nominal fee for consumers. Also, the ADR entity which has received a complaint notifies the parties to the dispute as soon as it has received all the documents containing the relevant information relating to the complaint. Furthermore, the outcome of the ADR procedure is made available within a period of 90 calendar days from the date on which the ADR entity has received the complete complaint file, except for the complex cases where this set period may be extended by informing parties about the expected length. Efficiency can also be achieved by setting efficient quality management systems (TQM, CAF or others) for CADR procedures, which the Directive is proposing through cooperation and information-exchange chapters. By ensuring strong mutual cooperation between ADR entities and national authorities with one model of measurement systems for CADR, we could achieve a high level of CADR efficiency, which would impact the reduction of overload of the courts and lead us to consistent public administration.

Beside administration convergence across Member states, these principles represent the foundation for uniformed EAS, which can be reflected through CADR systems and the implementation of these standards in all legislation fields, especially in practice. These principles can be useful in evaluating administration ca-

34 The solution imposed shall not result in the consumer being deprived of the protection afforded to him by the provisions that cannot be derogated from by agreement or by the mandatory rules of the law of the member state where the consumer and the trader habitually reside. 
pacity, civil-servant professionalism, rationality of decision-making and maybe a first step towards common European Administration Law. For this purpose, the EAS can also be described as a complex process based on Europeanization, Twinning, convergence or divergence and cross-border administration dynamics, but in the end, it can be empowered by CADR systems through their efficient proceedings in the EU.

\section{The statistical view of consumer ADR practice in Slovenian and Croatian public administration}

The current stage of CADR mechanisms in Slovenia and Croatia is not looking as efficient as it is priced in theory so far. Essentially, both member states have a huge number of litigation cases on the regular courts, which could be resolved faster, cheaper and more efficiently with ADR techniques. For example, if we compare the number of citizens with the number of litigation cases, we can argue that almost half the population is resolving their disputes in court in both selected countries. Croatia has on average almost twice as many court cases per year than Slovenia, which is expected because of the higher number of citizen (i.e. Croatia: 4 million, Slovenia: 2 million). The average of all on-going litigation cases in Croatia is approximately more than 2,000,000 per year, while in Slovenia the average is nearly $1,000,000$. Figure 1 shows the average of all litigation, mediation and administrative cases for a period of 6 years, from 2008 till 2013. In addition, Croatian courts receive nearly 1,600,000 litigation cases every year, more than half of which are unresolved $(787,984)$, while Slovenian courts from 801,427 litigation cases resolve more than half per year. Clearly all regular courts in both States are overloaded. To show a clear picture of the efficiency of court-annexed mediation as one of the main CADR schemes in both countries, we also compared all litigation cases to court-annexed mediation cases. The figure below also shows the inefficient use of mediation in Slovenian and Croatian courts. There is only $1 \%$ of resolved mediation cases in Slovenia $(5,750)$ and $0.3 \%$ in Croatian (996) compared to the average of all litigation cases.

Furthermore, Figure 1 also revealed that Slovenian (the administrative court) and Croatian administrative courts (four administrative courts and one higher administrative court) also submit a greater number of administrative cases, but compared to the huge number of all submitted litigation cases, there are only $1 \%$ of administrative cases in both countries. For example, the Slovenian administrative court receives nearly 13,000 administrative cases per year, of which more than half are resolved per year $(6,911)$. All Croatian administrative courts receive on average more than 15,000 administrative cases per year, 17,765 of which are resolved, but 31,177 
unresolved administrative cases per year still remain ${ }^{35}$. Clearly, both countries have built different structures of consumer protection under civil or administrative law. In this context, Slovenia has more administrative structure, where the main consumer protection body is the Inspectorate (TIRS), and it mainly resolves C2B relations with proposed final administrative decisions. Meanwhile Croatia has set a more civil version of consumer protection and has developed one high commercial court and eight commercial courts, which are competent to resolve C2B, B2C and B2B disputes with the final judicial decisions. Furthermore, the Croatian high commercial court and five commercial courts have imposed court-annexed mediation, while in Slovenia the main protection inspectorate still does not have any CADR mechanism. Figure 2 shows a comparison of the average litigation cases at the Croatian commercial courts with consumer complaints at the Consumer Protection Inspectorate in Slovenia. We see that a greater number of consumer protection cases exists. For instance, out of nearly 20,438 inspections in Slovenia, there are 9,280 issued administrative decisions, and out of approximately 194,551 cases in Croatia, 62,790 cases remain unresolved. In both member states, consumer protection structures are inefficient and complicated, which could be further improved through CADR systems.

\section{Figure 1}

Statistical comparison of the average of litigation, administration and courtannexed mediation cases at Croatian and Slovenian courts for 2008-2013

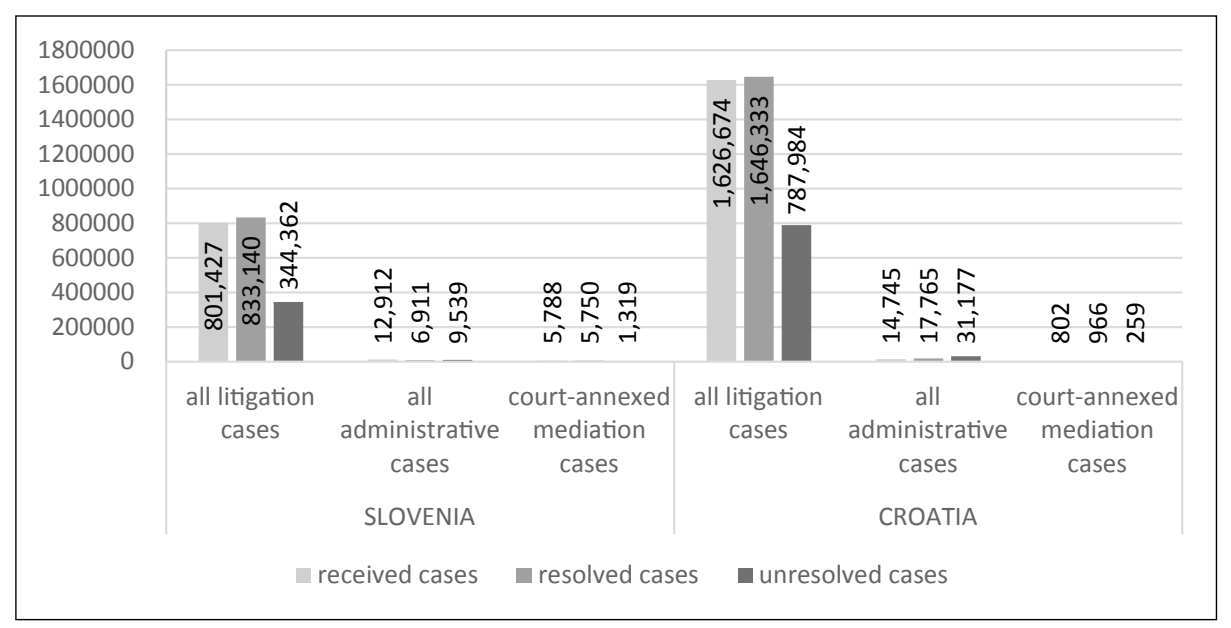

35 The reason for a higher average number of resolved administrative cases than received administrative cases is that The High Administrative Court was established after the year of 2013 and it had received all ongoing cases from all four Administrative courts. Therefore, in the years 2012 and 2013 Administrative courts have not received any administrative cases, but in this period all administrative cases (ongoing and received) were resolved by The High Administrative Court in Zagreb. After 2014 the administrative court structure was fully developed and today Croatia has four Administrative courts and one High Administrative court. 
Source: Annual reports of the Slovenian and Croatian Supreme courts, Croatian High Commercial court, Croatian commercial court in Zagreb for 2008-2013

\section{Figure 2}

Statistical comparison of the average of litigation cases or consumer complaint cases at the Croatian commercial courts and Slovenian consumer protection Inspectorate for 2008-2013

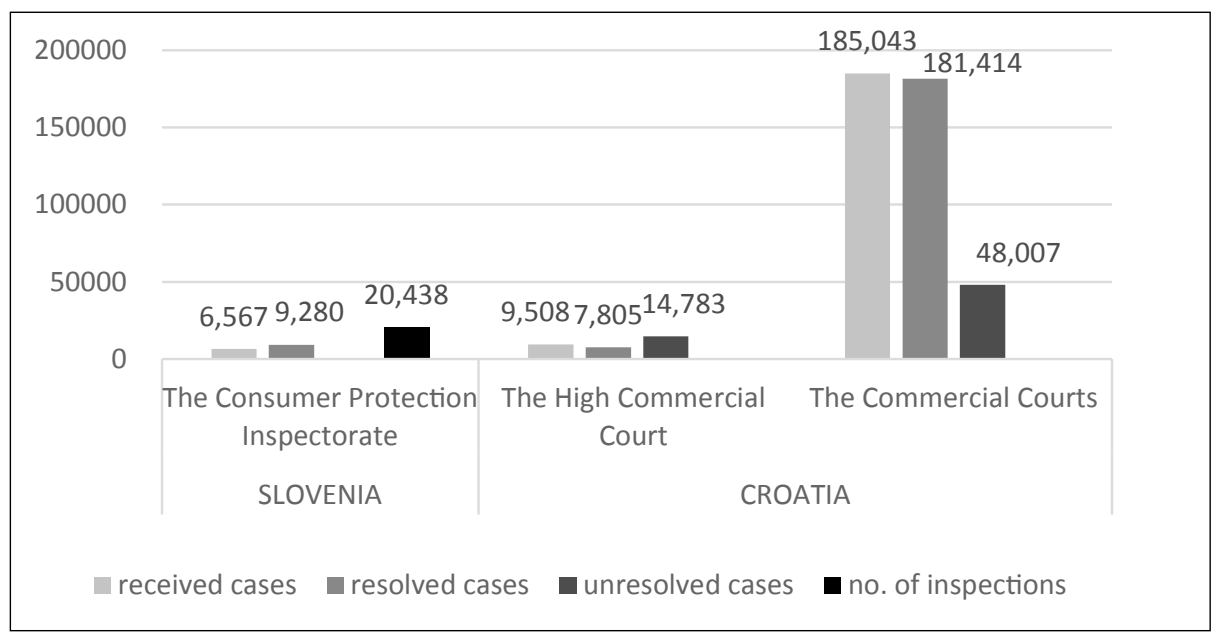

Source: Annual reports of Croatian Commercial courts and Slovenian CPI for 2008-2013

Additionally, a clear administrative consumer protection in both countries exists with different Regulatory agencies which possess CADR mechanisms, e.g. inhouse conciliation or complaint proceedings (ibid., 9). Out of 16 existing agencies in Slovenia, only two have CADR conciliation structure, such as Telecommunication (AKOS) and Energy Regulatory agencies (ARSE). While out of 44 agencies in Croatia, only five have CADR mechanisms, e.g. in-house complaint procedures, such as Telecommunication (HAKOM), Energy (HERA), Traffic (ATZP), Financial (FINA) and Health (AAZ) regulatory agencies. However, because of non-harmonized statistical data and an unequal set of CADR structures, we analyzed just two regulatory agencies, which provide similar consumer protection when it comes to dispute resolution. Figure 3 shows a comparison of the average of conciliation or complaint cases at Telecommunication regulatory agencies. Slovenian AKOS receives nearly 750 consumer complaints (telecommunication and postal) on average per year, 352 of which are resolved positively and 297 negatively by conciliation on average. From a greater number of negative conciliation cases, just 26 administrative appeals are brought before the Administrative court. HAKOM receives 1850 consumer complaints in Croatia, which is twice as much as Slovenian AKOS. By means of the in-house complaint structure, HAKOM on average resolves 440 cases 
positively and 615 negatively, 0.3 postal cases of which are filed before Administrative courts on average.

\section{Figure 3}

Statistical comparison of the average of consumer complaint cases at the Telecommunication regulatory agencies in Croatia (HAKOM) and Slovenia (AKOS) for 2008-2013

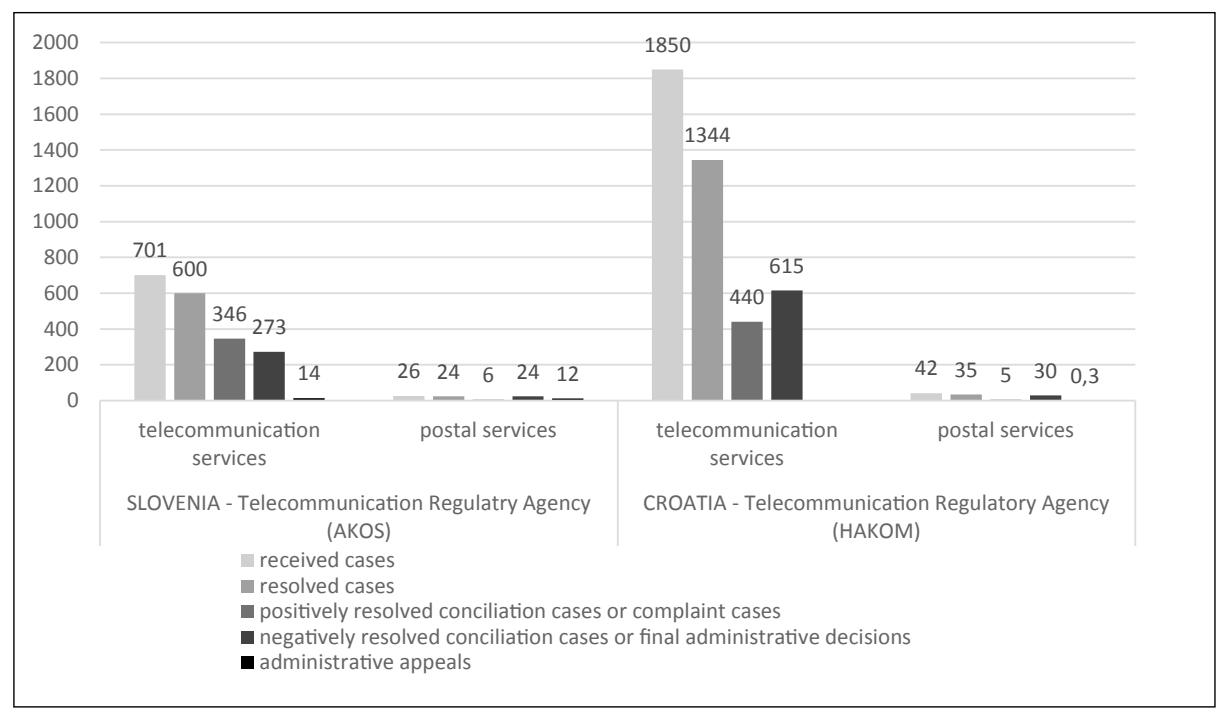

Source: Annual reports of Croatian HAKOM and Slovenian AKOS for 2008-2013

Additionally, the situation is a little bit different in the field of energy consumer dispute resolution. Figure 4 below shows a comparison of resolving consumer disputes in the fields of natural gas, district heat and electricity at the Energy regulatory agencies in Slovenia and Croatia. For example, the Slovenian energy regulatory agency (ARSE) receives 36 consumer complaints on average; the same number is resolved per year. Meanwhile, the Croatian energy regulatory agency (HERA) altogether receives 383 consumer complaints on average; almost the same number is resolved. In each member states, it is very rare that the consumer, after agencies' negative administrative decisions, submits an administrative appeal before the administrative courts, or that there is no common statistical data about these appeals. In both countries, there is no clear data in administrative courts' registers on the submitted administrative appeals that come from the unsuccessful CADR proceedings by Agencies or universal service providers. 


\section{Figure 4}

Statistical comparison of the average of consumer complaint cases at the Energy regulatory agencies in Slovenia (ARSE) and Croatia (HERA) for 2008-2013

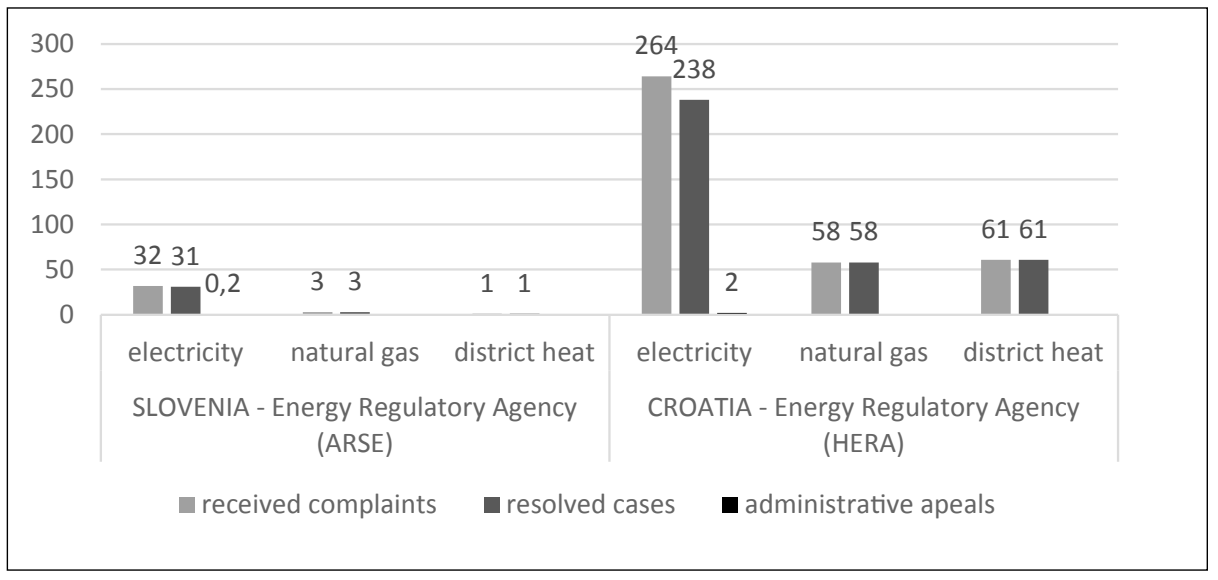

Source: Annual reports of Slovenian (ARSE) and Croatian (HERA) for 2008-2013

Essentially, an effective and certified CADR system for administrative consumer protection cases exists neither in Slovenia nor in Croatia. All governmental and non-governmental CADR institutions which are concerned with this particular field should be jointly responsible for raising the awareness of national consumers and consumers from other Member States about available CADR mechanisms. Implementing the new EU Directive with consumer information and educationpromotion campaigns is a starting point. Public administration authorities should be indirectly involved in these campaigns by providing support on the field of cofinancing, promotion, education, availability of CADR schemes in all CADR entities. Hopefully, the new CADR structure designed after the EU Directive on CADR and Regulation on ODR will ensure a higher level of consumer protection by raising consumers' confidence with empowerment.

\section{Important guidelines towards common European administrative space in the sense of good governance}

Important future guidelines towards more common and coherent EAS can be structured in the following groups:

1. A need for EU's action is the creation of a coherent CADR model in all legal fields with strong mutual cooperation between all public and private entities.

Essentially, there is a strong need to develop a coherent CADR framework not just for civil proceedings, but also within public-administration law across all 
member states. Through best-practice analysis of CADR systems across all of the EU, we could point out the successful structures of "administrative" CADR systems. For instance, both Belgium and the Netherlands have a strong, stable and effective structure of the CADR system, which combines a greater number of different CADR bodies (main or sector, private or public) with different CADR schemes. In fact, all CADR bodies are interconnected under one "Mediation umbrella", which reaches a high level of strong mutual cooperation. This so called "umbrella" also connects all CADR bodies online as the ODR system, which is even more visible and recognizable to all consumers and businesses in the country.

2. Building a strong, mutual cooperation with Communication Bridge between public and private bodies by building an efficient CADR cloud system on the national and international EU levels.

The creation of a coherent CADR model on the EU level, which can be transferred to domestic legal systems, would build a communication bridge with a strong mutual cooperation between all CADR entities in the Member states. All CADR entities will be interconnected and applied on one "EU hot-spot", where they would be visible to all EU consumers and business. The application of CADR entities to EC platform is now in the developing phase, which will last till the end of 2016.

3. The harmonization of the EU legal regulation in the field of consumer protection with an easy-transposable process into the national legislation.

Building a communication bridge with the creation of a CADR model could have a positive impact on the harmonization of EU legal regulation, but with a stronger supervision over a transposition process into the national legislation. The harmonization of the CADR legal regulation in the public-administration field would provide a consensus on the definitions in consumer disputes, such as common legal relationships of a legal nature, one legal structure with effective legal rights, efficient decisions with the resolved dilemmas about (non)binding out-comes etc.

4. A common EU model for Quality management tools and a coherent structure of statistical legal registers or annual case reports, mostly in the public administration.

With the use of integrated "Quality Management Tools - TQM" we could establish efficacious CADR systems in the private or public domains. For the effective quality measurement of CADR procedures, there is a need to develop a common structure to compare not just quantitative statistical data on CADR cases, but also to measure the perception and satisfaction of the parties, third neutral party and public authority involved in the process of dispute resolution. The Quality Management System should put the focus on the empowerment, behavior mea- 
surement and communication skills between all concerned parties in dispute (C2B/G or B2B/G). The comprehensive approach with different TQM methods provides a possibility to set new and simple "know how" methods, which could help improve consumer empowerment in the process of effective access to justice. Consumer confidence and satisfaction should be key factors of consensual dispute settlement.

\section{Conclusion}

The existence of administrative dilemmas in "administrative" CADR systems shows obstacles to effective consumer protection and their access to justice. Significant administrative aspects are made visible by observing CADR systems through public administration in the EU. Special attention has been given to CADR systems in selected Member states, where problems not only in non-harmonized legal conceptions and no consensus on the definitions of the parties involved are shown, but also in multi-stage proceedings as a consequence of the existing divergences in CADR systems held by different CADR public or private entities. Divergences in CADR systems point to a need for the EU's action to resolve sectoral diversity and the uneven geographical availability of CADR mechanisms. There exists a strong need for the development of one coherent CADR model across member states which would positively affect the harmonization process of CADR legal structure. To achieve a harmonized CADR legal structure, Member states have to establish coherent Quality management tools, which would ensure common statistical data on all CADR proceedings with the perception of all involved parties. This would show a clear picture of CADR systems in practice, which is so far leading to inefficient public governance. Furthermore, with the establishment of an effective CADR cloud, where all CADR systems would be interconnected on one "hot-spot", this would provide a higher level of visibility of the existing CADR systems across EU. The interconnection would build a strong communication bridge between all CADR entities in the EU and make CADR systems more effective and recognizable to not just consumers and business, but also to the public authorities. Therefore, this strategic plan would achieve the realization of set goals and principles of EAS through efficient CADR practice, which should lead us to a more common European administrative law.

Additionally, CADR and ODR mechanisms can be an "added value" with a "smart" regulation and empowered consumers and business, which puts them at the heart of the single market. According to Davies $(2012,63)$ the skills and capabilities of EU consumers nowadays represent an "intangible stock of capital", which means that empowered consumers will boost competition and innovation, which in turn will strongly influence economic growth and sustainability while also forcing businesses to deliver value on the market. Additionally, according to Macfarlane, (2012, p. 939) the essence of effective dispute resolution is innovation: “... To be effective innovators, we need to limit our preoccupation with rule-based change and explore 
other ways to support and build culture change..." The innovation component delivers value to the market, which means authentic commitment to trying something new and retaining an open mind to the results in practice. The effective CADR innovation in practice is empowering consumers with full confidence and changing the tradition of resolving their disputes (small claims), which are inefficient or even unconstitutional so far in daily practice.

\section{References}

Agrar, C. Haydar. 2012. Research of B2C and B2B International Markets in the Context of Benchmarking of European Union and Spain Performances. Master in International Business Administration and Languages. Universidad de Almería.

Barnes, Javier. 2009. Transforming Administrative Procedure: Towards a Third Generation of Administrative Procedures. Seville: Global Law Press.

Cardona, P. Francesco and Anke Freibert. 2007. "The European Administrative Space and Sigma Assessments of EU Candidate Countries." Hrvatska javna uprava 7(1), 51-59.

Cioclea, Elena A. 2012. "Principles of the European Administrative Space and their Impact on Performance in Public Organizations." CES Working Papers 3, 288-295.

The Commercial Court of Republic of Croatia. 2013. Annual Report of the Commercial Court in Period 2008-2013. Zagreb: Ministry of Justice, Republic of Croatia.

The Croatian Energy Regulatory Agency (HERA). 2013. Annual Reports for Consumer Complaints of HAKOM in Period 2008-2013. Zagreb: The Energy Regulatory Agency, Republic of Croatia.

The Croatian Telecommunication Regulatory Agency (HAKOM). 2013. Annual Reports for Consumer Complaints of HAKOM in Period 2008-2013. Zagreb: The Telecommunication Regulatory Agency, Republic of Croatia.

Davies, Jim. 2012. "How well Placed is the Optimism surrounding the new ADR/ODR Proposals?" Journal of European Consumer and Market Law 2, 63-64.

Directorate General for Health and Consumers - EC (DG SANCO). 2009. Study on the Use of Alternative Dispute Resolution in the European Union. Final Report. Civic Consulting of the Consumer Policy Evaluation Consortium. Berlin: Civic Consulting. 
Directorate General for Health and Consumers - EC (DG SANCO). 2011. Consultation Paper: On the Use of Alternative Dispute Resolution as a Means to Resolve Disputes Related to Commercial Transactions and Practices in the European Union. Berlin: Civic Consulting.

Directorate General for Health and Consumers - EC (DG SANCO). 2014. Management Plan 2014. Public Version. Brussels: European Commission.

Dragos, Dacian C., Neamtu, Bogdana (2014). Alternative Dispute Resolution in European Administrative Law. Berlin: Springer-Verlag Berlin Heidelberg.

European Commission. 2010. Europe 2020, a Strategy for Smart, Sustainable and Inclusive Growth. Communication from the Commission Brussels: COM (2010) 2020 final.

European Commission. 2011. Alternative Dispute Resolution for Consumer Disputes in the Single Market. Communication from the Commission to the European Parliament, the Council and the European Economic and Social Committee. Brussels: COM (791 final).

European Commission. 2011a. Regulation of the European Parliament and of the Council on a Consumer Programme 2014-2020. Brussels: COM (707 final), 0340 (COD).

European Commission. 2011b. Proposal for a Directive of the European Parliament and of the Council on Alternative Dispute Resolution for Consumer Disputes. Commission staff working paper, Brussels: 1409 final (SEC).

European Commission. 2012. Alternative Dispute Resolution and Online Dispute Resolution for EU consumers: Questions and Answers. MEMO. Brusselss: European Commission.

European Commission. 2012a. Single Market Act II, Together for New Growth. Communication from the commission to the European Parliament, the Council, the European Economic and Social Committee and the Committee of the Regions. Brussels: COM (2012) 573 final.

European Commission. 2013. Towards a European Horizontal Framework for Collective Redress. Communication from the Commission to the European Parliament, the Council, the European Economic and Social Committee and the Committee of the Regions. $\operatorname{COM(401~final).~}$

European Commission. 2013a. Regulation (EU) No 524/2013 of the European Parliament and of the Council of 21 May 2013 on Online Dispute Resolution for consumer disputes and amending Regulation (EC) No 2006/2004 and Directive 2009/22/EC (Regulation on consumer ODR).

European Commission. 2013b. Directive No 2013/11/EU of the European Parliament and of the Council of 21 May 2013 on Alternative Dispute Resolution for consumer disputes and amending Regulation (EC) No 2006/2004 and Directive 2009/22/EC (Directive on consumer ADR). 
The Gallup Organization. 2011. Flash Eurobarometer 299, "Consumer Attitudes towards Cross-Border Sales and Consumer Protection". The survey requested by EUROSTAT and DG-SANCO and coordinated by the Directorate-General for Communication.

Goes, Pieter. 2014. "Legal Framework relating to Alternative Dispute Resolution in Belgium Public Law." International Review for Public Administration 12(2-3), 9-31.

Herwig C. H. Hofmann, Jens-Peter Schneider and Jacques Ziller. (2014). ReNUAL Model Rules on EU Administrative Procedure. Book IV - contracts. Version for online publication. EU: Research Network on EU Administrative Law.

The High Commercial Court of Croatia. 2013. Annual Reports for Court-Annexed Mediation of the High Commercial Court in Period 2008-2013. Zagreb: Ministry of Justice, Republic of Croatia.

Hodges, Christopher. 2012. "Current Discussions on Consumer Redress: Collective Redress and ADR." Annual Conference on European Consumer Law organized by ERA Forum 13, 11-33.

Hodges, Christopher, Iris Benöhr and Naomi Creutzfeldt-Banda. 2012. A Model for a National Consumer ADR Architecture. Adopted from Consumer ADR in Europe. Oxford: University of Oxford, Centre for socio-legal studies.

Hodges, Christopher, Iris Benöhr and Naomi Creutzfeldt-Banda. 2012a. Essential Requirements and Key Performance Indicators. Adopted from Consumer ADR in Europe. University of Oxford: Centre for socio-legal studies.

Hodges, Christopher, Iris Benöhr and Naomi Creutzfeldt-Banda. 2012b. Consumerto-Business ADR Structures: Harnessing the Power of CADR for Dispute Resolution and Regulating Market Behavior. Oxford: European Civil Justice Systems, The Foundation for Law, Justice and Society in collaboration with the University of Oxford: Centre for Socio-Legal Studies.

Hodges, Christopher, Iris Benöhr and Naomi Creutzfeldt-Banda. 2012c. Data on the Costs of Consumer ADR Schemes. Oxford: University of Oxford: Center for Socio-Legal studies.

Hodges, Christopher, Iris Benöhr and Naomi Creutzfeldt-Banda. 2012d. Consumer $A D R$ in Europe. Oxford, Portland, Oregon. United Kingdom: Hart Publishing.

Jeretina, Urša and Uzelac, Alan. 2014. Alternative Dispute Resolution for Consumer Cases: Are Divergences an Obstacle to Effective Acces to Justice? International Review for Public Administration (IPAR), Vol. XII (4), 39-72. Ljubljana: Faculty of Administration, University of Ljubljana. 
Juškys, A. and N. Ulbaitè. 2012. "Alternative Dispute Resolution for Consumer Disputes in the European Union: Current Issues and Future Opportunities." Issues of Business and Law 4, 25-34.

Koprić, Ivan, Polona Kovač and Anamarija Musa. 2012. "Agencies between Expertise, Politics and Law: The Case of Countries in Transition in South Eastern Europe." Budapest: $5^{\text {th }}$ NISPAcee-EGPA Trans-European Dialogue (TED5), 2-3 February 2012.

Lindell, Bengt. 2012. "Alternative Dispute Resolution and the Administration of Justice - Basic Principles." Scandinavian Studies (1999-2012), 312-344.

Macfarlane, Julie. 2012. "ADR and the Courts: Renewing our Commitment to Innovation." Marquette Law Review 95(3), article 9.

OECD-PUMA. 1999. European Principles for Public Administration. Sigma papers 27. Place: OECD Publishing, Paris, France.

Perritt Jr., Henry H. 1987. "Administrative Alternative Dispute Resolution: The Development of Negotiated Rulemaking and Other Processes." Pepperdine Law Review 14(4), 864-928.

Rous, Helena (2014). Novi trendi EU glede alternativnega reševanja sporov preko spleta. Pravna Praksa, No. 12/14, 16-18. Ljubljana: Faculty of Law, University of Ljubljana.

The Slovenian Energy Regulatory Agency (ARSE). 2013. Annual Reports for Consumer Complaints of ARSE in Period 2008-2013. Ljubljana: The Energy Regulatory Agency, Republic of Slovenia.

The Slovenian Telecommunication Regulatory Agency (AKOS). 2013. Annual Reports for Consumer Complaints of AKOS in Period 2008-2013. Ljubljana: The Telecommunication Regulatory Agency, Republic of Slovenia.

The Supreme Court of Republic of Slovenia. 2013. Annual Reports for Court-Annexed Mediation in Period 2008-2013. Ljubljana: Ministry of Justice, Republic of Slovenia.

The Supreme Court of Republic of Slovenia. 2013a. Annual Reports of the Supreme Court in the Period 2008-2013. Ljubljana: Ministry of Justice, Republic of Slovenia.

TNS Opinion \& Social. 2011. Special Euro barometer 342, "Consumer Empowerment". The survey requested by EUROSTAT and DG-SANCO and coordinated by the Directorate-General for Communication.

Uzelac, Alan, S. Aras, M. Maršić, M. Mitrović, Ž. Kauzlarić and P. Stojčević. 2010. Aktualni trendovi mirnog rješavanja sporova u Hrvatskoj: dosezi i ograničenja. Zbornik Pravnog fakulteta u Zagrebu 60(3), 1265-1308. Zagreb: Faculty of Law, University of Zagreb. 